\title{
The interrelationship between the cardiovascular remodeling indicators and the state of bone mineral density in women with coronary artery disease
}

\author{
N. S. Mykhailovska ${ }^{A, E, F}$, I. O. Stetsiuk*B,C,D \\ Zaporizhzhia State Medical University, Ukraine
}

A - research concept and design; B - collection and/or assembly of data; C - data analysis and interpretation; D - writing the article; $\mathrm{E}$ - critical revision of the article; $\mathrm{F}$ - final approval of the article

Objective. To determine the peculiarities of the interrelationship between the cardiovascular remodeling indicators and the state of bone mineral density (BMD) in women with coronary artery disease (CAD).

Methods. A double open cross-sectional monocentric clinical study in parallel groups involved 115 women in postmenopausal period with coronary artery disease (CAD): stable exertional angina of II-III functional class. Depending on the BMD state they were divided into 3 groups: group 1 - 24 patients with normal BMD; group $2-34$ patients with osteopenia; group $3-44$ patients with osteoporosis. The BMD state was assessed with the help of ultrasound densitometry combined with FRAX algorithm. The structural and functional parameters of the heart and blood vessels were determined using the two-dimensional echocardiography and pulsed-wave Doppler imaging.

Results. It was established that in women with CAD there was a significant decrease in T- and Z-criteria and an increase in the 10-year risk of developing of osteoporosis fractures, depending on the severity of BMD loss. The presence of postmenopausal osteoporosis in women with coronary artery disease was associated with a significant increase in thickness of the intima-media complex of the right and left common carotid artery (by $14.94 \%$ and $15.56 \%$ respectively), LV PWd (by $9.26 \%$ ), and LV Myocardial stiffness index (by $40.00 \%$ ), decreased LV EF (by $8.77 \%$ ), development of the LV diastolic dysfunction by the type of the impaired relaxation (in $80.76 \%$ ), formation of predominantly concentric hypertrophy of LV (in $68.18 \%$ of cases) and an increase in the incidence of LV eccentric hypertrophy compared to patients with normal BMD (11.36 \% vs. $4.17 \%$; $\left.X^{2}=4.267 ; \mathrm{df}=1 ; \mathrm{P}<0.05\right)$. In women with coronary artery disease and BMD abnormalities, the number of patients with heart valves calcification was significantly higher: $60.00 \%$ in the group with osteopenia, $77.42 \%$ in the group with osteoporosis in comparison with $28.58 \%$ in the group with normal BMD; there was an increase in the incidence of calcinosis identification in two or more heart valves. The existence of a correlative dependence was established between T-and Z-criteria of the radial bone and LV EF $(r=+0.42$; $P<0.05)$, LV ESV $(r=+0.61$; $<<0.05)$, between Z-criteria of the radius, the 10-year risk of development of fractures of the radial bone and tibia and $\operatorname{LAD}(r=+0.43 ; P<0.05 ; r=+0.50 ; P<0.05$ respectively), between the 10 -year risk of the development of the tibial fractures and LVM $(r=+0.58 ; P<0.05)$

Conclusions. Changes in the structural and functional parameters of the heart in women with coronary artery disease progress depending on the severity of BMD loss, which indicates the interrelationship of bone and cardiovascular remodeling.

\section{Взаємозв'язок показників кардіоваскулярного ремоделювання зі станом мінеральної щільності кісткової тканини в жінок з ішемічною хворобою серця}

\section{Н. С. Михайловська, І. О. Стецюк}

Мета роботи - визначити особливості взаємозв'язку показників кардіоваскулярного ремоделювання зі станом мінеральної щільності кісткової тканини (МЩКТ) у жінок з ішемічною хворобою серця (IXC).

Матеріали та методи. До подвійного відкритого, поперечного, моноцентрового клінічного дослідження в паралельних групах залучили 115 жінок у постменопаузальному періоді з діагнозом IXC: стабільна стенокардія напруження II-III ФК. Залежно від стану МЩКТ пацієнток поділили на 3 групи: 1 група - 24 хворих із нормальними показниками МЩКТ, 2 група - 34 пацієнти з остеопенією, 3 група - 44 особи з остеопорозом. Стан МЩКТ вивчили за допомогою ультразвукової остеоденситометрії та алгоритму FRAX. Структурно-функціональні показники серця та судин визначали за допомогою двовимірної ехокардіоскопії та імпульсно-хвильової доплерографрії.

Результати. У жінок з IXC спостерігали вірогідне зниження Т- та Z-критерію та збільшення 10-річного ризику розвитку остеопорозних переломів залежно від ступеня порушень МЩКТ. Наявність постменопаузального остеопорозу в жінок з IXC асоційована з вірогідним збільшенням КІМ правої та лівої ЗСА (на 14,94 \% та 15,56 \% відповідно), ТЗСлШ (на $9,26 \%$ ) та індексу жорсткості міокарда ЛШ (на 40,00 \%), зниженням ФВ ЛШ (на 8,77 \%), розвитком діастолічної дисфункції ЛШ за типом порушення релаксації (у 80,76 \%), фрормуванням переважно концентричної гіпертрофії ЛШ (у 68,18 \%) та збільшенням частоти розвитку ексцентричної гіпертрофрії ЛШ порівняно з хворими з нормальним станом МЩКТ (11,36 \% проти 4,17 \%; $\left.\chi^{2}=4.27 ; \mathrm{df}=1 ; \mathrm{p}<0,05\right)$. Серед жінок з IXC і порушеннями МЩКТ вірогідно переважала кількість хворих, які мають кальциноз клапанів серця: 60,00 \% у групі з остеопенією, 77,42 \% у групі з остеопорозом проти 28,58 \% у групі з нормальними показниками МЩКТ; спостерігали збільшення частоти виявлення кальцинозу 2 i більше клапанів серця. Встановили наявність кореляційного взаємозв'язку між Т- та Z- критерієм променевої кістки та ФВ ЛШ $(r=+0,42 ; p<0,05)$, КСР ЛШ ( $r=+0,61 ; p<0,05)$, між Z-критерієм променевої кістки, 10-річним ризиком розвитку
Key words: myocardial ischemia, postmenopause osteoporosis, bone density, artrial remodeling, correlation of data.

Pathologia 2019; 16 (1), 53-59 Dol: 10.14739/2310-1237. 2019.1.166296

*E-mail: iryna.zsmu@gmail.com 
переломів променевої кістки й великогомілкової кісток та ЛПд ( $r=+0,43 ; p<0,05 ; r=+0,50 ; p<0,05$ відповідно), між 10 -річним ризиком розвитку переломів великогомілкової кістки та ММЛШ $(r=+0,58 ; p<0,05)$.

Висновки. Зміни структурно-функціональних показників серця в жінок з IXC прогресують залежно від ступеня виразності порушень МЩКТ, що свідчить про взаємозв'язок кісткового та кардіоваскулярного ремоделювання.

Ключевые слова: ишемическая болезнь сераца, постменопауза, остеопороз, кости плотность, ремоделирование сераца, взаимосвязь.

Патология. - 2019. T. 16, № 1(45). C. 53-59

\section{Взаимосвязь показателей кардиоваскулярного ремоделирования с состоянием минеральной плотности костной ткани у женщин с ишемической болезнью сердца}

\section{Н. С. Михайловская, И. О. Стецюк}

Цель работы - определить особенности взаимосвязи показателей кардиоваскулярного ремоделирования с состоянием минеральной плотности костной ткани (МПКТ) у женщин с ишемической болезнью сердца (ИБС).

Материалы и методы. В двойное, открытое, поперечное, моноцентровое клиническое исследование в параллельных группах включены 115 женщин в постменопаузальном периоде с диагнозом ИБС: стабильная стенокардия напряжения II-III ФК. В зависимости от состояния МПКТ пациенток поделили на 3 группы: 1 группа - 24 больных с нормальными показателями МПКТ, 2 группа - 34 пациентки с остеопенией, 3 группа - 44 женщины с остеопорозом. Состояние МПКТ изучали при помощи ультразвуковой остеоденситометрии и алгоритма FRAX. Структурно-функциональные показатели сердца и сосудов определяли с помощью двумерной эхокардиоскопии и импульсно-волновой допплерографии.

Результаты. У женщин с ИБС наблюдали достоверное снижение Т- и Z-критерия и увеличение 10-летнего риска развития остеопорозных переломов в зависимости от степени нарушений МПКТ. Наличие постменопаузального остеопороза у женщин с ИБС ассоциировано с достоверным увеличением КИМ правой и левой ОСА (на 14,94 \% и $15,56 \%$ соответственно), ТЗСЛЖ (на 9,26 \%) и индекса жесткости миокарда ЛЖ (на 40,00 \%), снижением ФВ ЛЖ (на $8,77 \%$ ), развитием диастолической дисфункции ЛЖ по типу нарушения релаксации (у 80,76 \%), формированием преимущественно концентрической гипертрофии ЛЖ (у 68,18 \%) и увеличением частоты развития эксцентрической гипертрофии ЛЖ по сравнению с больными с нормальным состоянием МПКТ $\left(11,36 \%\right.$ против 4,17 \%; $\chi^{2}=4,27 ; \mathrm{df}=1$; p < 0,05). Среди женщин с ИБС и нарушениями МПКТ достоверно преобладало количество больных, имеющих кальциноз клапанов сердца: 60,00 \% в группе с остеопенией, 77,42 \% в группе с остеопорозом против 28,58 \% в группе с нормальными показателями МПКТ; наблюдали увеличение частоты обнаружения кальциноза 2 и более клапанов сердца. Установлено наличие корреляционной взаимосвязи между Т- и Z-критерием лучевой кости и ФВ ЛЖ $(r=+0,42$; $p<0,05)$, КСР ЛЖ ( $r=+0,61 ; p<0,05)$, между Z-критерием лучевой кости, 10-летним риском развития переломов лучевой, большеберцовой костей и ЛПд ( $r=+0,43 ; p<0,05 ; r=+0,50 ; p<0,05$ соответственно), между 10-летним риском развития переломов большеберцовой кости и ММЛШ ( $r=+0,58 ; p<0,05)$.

Выводы. Изменения структурно-функциональных показателей сердца у женщин с ИБС прогрессируют в зависимости от степени выраженности нарушений МПКТ, что свидетельствует о взаимосвязи костного и кардиоваскулярного ремоделирования.

\section{Introduction}

According to the World Health Organization (WHO), among the elderly people all over the world women predominate: their proportion at the age of 60 years and older is $54 \%$, at the age of 75 years and older - almost $60 \%$, and at the age of 90 years and older - about $70 \%$. Today, the proportion of elderly women is constantly increasing, which requires studying the health state of women in the postmenopausal period [1].

Menopause is an inalienable natural biological process which occurs in women of the average age of 50 , and which is established after 12 months of nonpathological amenorrhea and characterized with a progressing deficiency of sex hormones [2]. Recently, it was considered that the natural level of sex hormones in women renders a cardioprotective effect. However, over the last decade, the views on the development of probable cardiovascular complications in women, especially in the postmenopausal period, have significantly changed [3]. Since the onset of menopause, which accelerates the development of dyslipidaemia, insulin resistance and obesity, the incidence of coronary artery disease in the female population significantly increases, equating, and in future even exceeding such in men [4].
Besides, in the menopause period, a decrease in bone mineral density with the further development of systemic osteoporosis is observed, which is characterized by negative changes of microarchitectonics and increased bone fragility and the increased risk of osteoporosis fractures [5,6]. In Ukraine, osteoporosis is observed in $13.4 \%$ of female and in $2.9 \%$ of male population. With age, the proportion of patients with osteoporosis increases up to $22.0 \%$ in men and up to $53.0 \%$ in women [7]. According to other national data, the prevalence of osteoporosis among the adult population of Ukraine is about 20-39\% in women and 9-23\% in men (depending on the region of residence), with a high risk of fractures - up to $10.7 \%$ [7]. According to dual-energy X-ray densitometry, $11 \%$ of women in Ukraine have osteoporosis at the femoral neck level, $20 \%$ and $24 \%$ respectively - in the spinal column and forearm area. According to the International Osteoporosis Foundation, the number of Ukrainian women in postmenopausal period with osteoporosis and osteopenia is equal to 7 million ( $28 \%$ of the total number of women) [7].

Today, in the older age groups, the combination of CAD with bone marrow pathology, in particular osteoporosis, is recognized more frequently [8]. A close interrrelationship between BMD indices and cardiovascular 
diseases risk has been proven $[9,10]$. In osteoporosis, as in atherosclerosis, the similar processes occur: key proteins of bone metabolism (in particular, osteocalcin, osteoprotegerin, bone morphogenic protein, matrix Gla protein, osteonectin, osteopontin, etc.) are detected in the components of the vascular matrix, and under the progression of atherosclerotic lesion of the heart and blood vessels, the concentration of some of them significantly increases [11-13]. Modern scientific data also provide the evidence of their participation in the development of cardiovascular remodeling [12].

Therefore, it is important to investigate the interrelationship between cardiovascular and bone remodeling in women with coronary artery disease, associated with postmenopausal osteoporosis in order to find common determinants of development and progression, as well as to develop differentiated approaches to diagnosing and treatment of this comorbidity.

\section{Objective}

To determine the peculiarities of the interrelationship between the cardiovascular remodeling indicators and the BMD state in women with CAD.

\section{Materials and methods}

A double open cross-sectional monocentric clinical study in parallel groups involved 115 women in the postmenopausal period with CAD: stable exertional angina of II-III functional class. Depending on the BMD state, all patients were divided into 3 groups: group $1-24$ patients with normal BMD (T-criterion is more than -1 SD); group 2 - 34 patients with osteopenia (T-criterion is from - 1 SD to -2.5 $\mathrm{SD}$ ); group $3-44$ patients with osteoporosis (T-criterion is less than $-2.5 \mathrm{SD}$ ).

Criteria for the patient to be included into the study were the following: presence of verified (documented) stable exertional angina of II-III FC; the duration of the postmenopausal period in women for more than 5 years, informed consent of the patient. The exclusion criteria: diseases inducing the development of secondary osteoporosis; severe arterial hypertension, severe chronic somatic pathology; cancer, mental disorders and systemic diseases; alcohol abuse, drug addiction.

Angina pectoris was diagnosed according to the classification of the Canadian Association of Cardiologists. The BMD state was assessed according to $\mathrm{WHO}$ criteria (1994). The degree of BMD loss was evaluated according to the T-criterion (the standard deviations' value - SD from the mean values of the "peak bone mass») using the ultrasonic osteodensitometry method on the Omnisense 7000 apparatus with sensors for the phalanx of the finger, the radial and tibia bones. The FRAX algorithm was used to assess the 10-year risk of osteoporotic fractures development.

Two-dimensional echocardiography and pulse-wave dopplerography were performed at the Esaote MyLab 50 Xvision ultrasound scanner under the generally accepted practice according to ASE/EAE recommendations (2011). The following parameters were determined (sm): the size of the left atrium (LA-AP) and the aorta (Ao), the size of the right atrium (RAD) and the right ventricle (RVD), the end-diastolic (EDD, sm), and the end-systolic sizes (ESD, sm) of the left ventricle (LV), the posterior wall thickness (LV PWd, sm), the interventricular septum thickness (IVSd). The end-diastolic volume (LV EDV, $\mathrm{ml}$ ), end-systolic volume (LV ESV, $\mathrm{ml}$ ) were calculated by the Simpson method (1991), the left ventricular ejection fraction (LVEF, \%), the mass of the myocardium of the LV (LVM, g) were determined. Taking into account the individual constitutional features of patients, in determining the myocardial mass index (LVMI, $\left.g / \mathrm{m}^{2}\right)$, the indexing of the value to the surface area of the body was used. The myocardial stiffness index of the LV (LV Myocardial stiffness index, $\mathrm{mm} \mathrm{Hg} / \mathrm{ml}$ ), (\%) was determined according to E. I. Chazov (1992).

In order to assess the transmitral diastolic blood flow, the maximal velocity of the early $(\mathrm{Ve}, \mathrm{sm} / \mathrm{sec})$ and late (Va, sm/sec) LV filling, their correlation (Ve/Va, units), the time of isovolumic relaxation of the LV (IVRT, ms) and the deceleration time of early diastolic filling (DT, $\mathrm{ms}$ ) were determined. Evaluation of the types of LV remodeling was carried out according to the A. Ganau et al. classification (1992).

Quantitative and qualitative characteristics of the state of the intima-media complex (IMC) of the common carotid arteries (CCA) were evaluated under the ultrasound visualization in B-mode. An increase in the thickness of IMC greater than $0.9 \mathrm{~mm}$ was considered as a marker of atherosclerotic vascular damage.

In the following study the principles of bioethics were respected: the main provisions of the European Convention on Human Rights and Biomedicine (from 04.04.1997), GCP (1996), Helsinki Declaration of the World Medical Association on the Ethical Principles of Human Medical Scientific Research (1964-2000) and the Ministry of Health of Ukraine Order No. 281 dated back to 01.11 .2000 .

Statistical data processing was carried out by using the method of variation statistics with the help of software package "Statistica 13.0". (StatSoft Inc., № JPZ8041382130ARCN10-J), under the generally accepted practice. The pattern of the distribution of the studied variables was assessed using the Shapiro-Wilk's criterion. Quantitative characteristics were represented as $\mathrm{M} \pm \mathrm{m}$ (arithmetic mean \pm standard error of arithmetic mean) or $\mathrm{Me}\left(\mathrm{Q}_{25} ; \mathrm{Q}_{75}\right)$ (median, 25 and 75 distribution quartiles) depending on the type of data distribution. Under the normal distribution, the validity of the differences was estimated using the Student's t-criterion; under the distribution different from normal, Mann-Whitney's non-parametric U-criterion was used. The assessment of the interrelationship between pairs of independent indexes, expressed in quantitative scale, was performed by calculating Pearson rank correlation coefficients (under the normal distribution) and Spearman rank correlation coefficients (under the distribution different from normal). Comparison of groups on a qualitative basis, as well as in the study of the frequency of detection of indicators, was carried out using the criterion $X^{2}$ with the analysis of conjugation tables. Differences were considered statistically significant at $P<0.05$. 


\section{Results}

The results of the assessment of the BMD state and the 10-year risk of osteoporotic fractures development in women with coronary artery disease in the postmenopausal period are presented in Table 1.

The presence of osteopenia or osteoporosis in

Table 1. BMD state in women with coronary artery disease in the postmenopausal period $(\mathrm{M} \pm \mathrm{m})$

\begin{tabular}{|c|c|c|c|}
\hline $\begin{array}{l}\text { Indicator, units } \\
\text { of measurement }\end{array}$ & CAD $(n=24)$ & $\begin{array}{l}\text { CAD + osteopenia } \\
(n=34)\end{array}$ & $\begin{array}{l}\text { CAD + osteoporosis } \\
(n=44)\end{array}$ \\
\hline T-criterion phalanx,SD & $-0.17 \pm 0.21$ & $-1.39 \pm 0.20^{\star \star \star}$ & $-2.17 \pm 0.22^{\star \star *}$ \\
\hline T-criterion radius, SD & $-0.31 \pm 0.26$ & $-1.73 \pm 0.16^{* * *}$ & $-3.15 \pm 0.20^{* * *}$ \\
\hline T-criterion tibia, SD & $0.13 \pm 0.21$ & $-0.78 \pm 0.26^{\star * *}$ & $-1.43 \pm 0.31^{* * *}$ \\
\hline Z-criterion phalanx, SD & $1.49 \pm 0.24$ & $0.35 \pm 0.20^{* * *}$ & $-0.16 \pm 0.21^{\star * *}$ \\
\hline Z-criterion radius, SD & $1.18 \pm 0.33$ & $-0.01 \pm 0.19^{* * *}$ & $-1.13 \pm 0.23^{* * *}$ \\
\hline Z-criterion tibia, SD & $1.49 \pm 0.21$ & $0.69 \pm 0.31^{*}$ & $0.25 \pm 0.32^{* * *}$ \\
\hline $\begin{array}{l}\text { Fracture risk } \\
\text { (phalanx), \% }\end{array}$ & $4.24 \pm 0.70$ & $9.56 \pm 1.20^{* * *}$ & $18.31 \pm 2.53^{* * *}$ \\
\hline $\begin{array}{l}\text { Fracture risk } \\
\text { (radius), \% }\end{array}$ & $6.38 \pm 0.96$ & $12.68 \pm 0.94^{* * *}$ & $32.48 \pm 3.70^{\star * *}$ \\
\hline Fracture risk (tibia), \% & $10.81 \pm 1.10$ & $12.18 \pm 0.75$ & $18.22 \pm 1.58^{\star * *}$ \\
\hline
\end{tabular}

$*, * *, * * *$ : the probability of indexes difference if compared to the patients with CAD and normal BMD state $(\mathrm{P}<0.05 ; \mathrm{P}<0.01 ; \mathrm{P}<0.001)$.

Table 2. Structural and functional parameters of heart and vessels in women with coronary artery disease in the postmenopausal period, depending on the degree of $B M D$ loss, $M \pm m ; M e\left(Q_{25} ; Q_{75}\right)$

\begin{tabular}{|c|c|c|c|}
\hline $\begin{array}{l}\text { Indicator, units } \\
\text { of measurement }\end{array}$ & $\begin{array}{l}\text { CAD } \\
(n=24)\end{array}$ & $\begin{array}{l}\text { CAD + osteopenia } \\
(n=34)\end{array}$ & $\begin{array}{l}\text { CAD + osteoporosis } \\
(n=44)\end{array}$ \\
\hline $\begin{array}{l}\text { IMC thickness } \\
\text { of the right CCA, mm }\end{array}$ & $0.87 \pm 0.03$ & $0.92 \pm 0.03$ & $1.00 \pm 0.02^{*}$ \\
\hline $\begin{array}{l}\text { IMC thickness } \\
\text { of the left CCA, mm }\end{array}$ & $0.90 \pm 0.03$ & $0.96 \pm 0.03$ & $1.04 \pm 0.03^{*}$ \\
\hline Ao, sm & $2.10(1.9 ; 2.6)$ & $2.10(1.9 ; 2.6)$ & $2.10(1.90 ; 2.40)$ \\
\hline LA-AP, sm & $4.10(3.70 ; 4.40)$ & $3.95(3.60 ; 4.30)$ & $3.90(3.60 ; 4.30)$ \\
\hline LV EDD, sm & $4.91(4.75 ; 5.15)$ & $5.00(4.80 ; 5.20)$ & $4.80(4.60 ; 5.00)$ \\
\hline LV EDV, ml & $\begin{array}{l}115.00(98.00 \\
121.00)\end{array}$ & $115.00(104.00 ; 126.00)$ & $\begin{array}{l}117.00(99.00 \\
122.00)\end{array}$ \\
\hline LV ESD, sm & $3.00(2.97 ; 3.20)$ & $3.04(2.80 ; 3.40)$ & $2.99(2.20 ; 4.70)$ \\
\hline LV ESV, ml & $43.50(36.00 ; 47.00)$ & $47.00(39.00 ; 52.00)$ & $50.00(45.00 ; 60.00)^{*}$ \\
\hline $\begin{array}{l}\text { LV Myocardial stiffness } \\
\text { index, } \mathrm{mm} \mathrm{Hg} / \mathrm{ml}\end{array}$ & $0.10(0.10 ; 0.13)$ & $0.12(0.07 ; 0.14)$ & $0.14^{*}(0.13 ; 0.18)$ \\
\hline IVSd, sm & $1.11(1.06 ; 1.23)$ & $1.12(1.01 ; 1.18)$ & $1.14(1.10 ; 1.20)$ \\
\hline LV PWd, sm & $1.08(1.02 ; 1.18)$ & $1.15(1.03 ; 1.20)$ & $1.18(1.10 ; 1.20)^{\star}$ \\
\hline LV EF, \% & $62.00(57.50 ; 63.00)$ & $58.00(54.00 ; 62.00)$ & $57.00(49.00 ; 61.00)^{*}$ \\
\hline LVM, g & $\begin{array}{l}216.00 \\
(194.00 ; 227.00)\end{array}$ & $\begin{array}{l}217.00 \\
(170.00 ; 242.00)\end{array}$ & $\begin{array}{l}222.00 \\
(198.00 ; 250.00)\end{array}$ \\
\hline LVMI, $g / m^{2}$ & $\begin{array}{l}107.50 \\
(87.00 ; 115.00)\end{array}$ & $\begin{array}{l}113.00 \\
(96.00 ; 130.00)\end{array}$ & $\begin{array}{l}112.00 \\
(106.00 ; 129.00)\end{array}$ \\
\hline RVD, sm & $3.00(2.40 ; 3.30)$ & $2.70(2.60 ; 3.10)$ & $2.80(2.50 ; 3.10)$ \\
\hline $\mathrm{RAD}, \mathrm{sm}$ & $4.40(3.85 ; 4.40)$ & $4.00(3.70 ; 4.30)$ & $4.10(3.70 ; 4.30)$ \\
\hline
\end{tabular}

$*, * *, * * *$ : the probability of indexes difference if compared to the patients with CAD and normal BMD state $(P<0.05 ; P<0.01 ; P<0.001)$.

Table 3. Indices of transmitral blood flow in CAD women, depending on the degree of BMD loss $(\mathrm{M} \pm \mathrm{m})$

\begin{tabular}{l|l|l|l|}
$\begin{array}{l}\text { Indicator, units } \\
\text { of measurement }\end{array}$ & CAD $(\mathbf{n = 2 4 )}$ & $\begin{array}{l}\text { CAD }+ \text { osteopenia } \\
(\mathbf{n}=\mathbf{3 4})\end{array}$ & $\begin{array}{l}\text { CAD +osteoporosis } \\
(\mathbf{n}=\mathbf{4 4})\end{array}$ \\
\hline $\mathrm{Ve} / \mathrm{Va}$ & $0.94 \pm 0.06$ & $0.87 \pm 0.04$ & $0.83 \pm 0.04$ \\
IVRT, ms & $76.71 \pm 3.07$ & $78.94 \pm 2.72$ & $80.57 \pm 1.90$ \\
\hline $\mathrm{DT}, \mathrm{ms}$ & $160.00 \pm 8.28$ & $188.53 \pm 8.14^{*}$ & $193.64 \pm 6.38^{*}$ \\
\hline
\end{tabular}

$*, * *, * * *$ : the probability of indexes difference if compared to the patients with CAD and normal BMD state $(P<0,05 ; P<0,01 ; P<0,001)$. the corresponding group was verified by a significant decrease in T- and Z-criteria and an increase in the 10-year risk of osteoporosis fractures development.

The peculiarities of cardiovascular remodeling in women with coronary artery disease, depending on the degree of BMD loss are presented in Table 2.

In the CAD and osteopenia group the mean value of the IMC thickness of the left and right CCA tended to increase, while in the CAD and osteoporosis group it significantly exceeded the corresponding indices in the CAD and normal BMD group by $14.94 \%$ and by $15.56 \%(P<0.05)$. At the same time, in women with CAD and postmenopausal osteoporosis, a larger number of patients showed the increase in the IMC thickness: $88.33 \%$ vs. $30.00 \%$ in the group of women with normal $\operatorname{BMD}\left(X^{2}=6.42 ; d f=1 ; P<0.05\right)$.

The structural and functional parameters of the heart

in women with CAD and osteopenia did not demonstrate a significant difference, if compared to the women with normal BMD, but LV ESV, LVMI, LV PWd parameters tended to increase, and LV EF tended to decrease if compared to the women with normal BMD. In women with $\mathrm{CAD}$, combined with postmenopausal osteoporosis, there was a tendency to the increase in LV EDV, the IVSd thickness and the LVMI, and a significant increase in the LV PWd by $9.26 \%$ and in the LV ESV by $14.94 \%$ $(P<0.05)$, which indicates a greater degree of LVH in this category of patients. In patients with postmenopausal osteoporosis, an incease in the LV Myocardial stiffness index by $40.00 \%$ was observed, if compared to the CAD and normal BMD group $(P<0.05)$. In patients with $C A D$, combined with postmenopausal osteoporosis, in contrast to the CAD and normal BMD group, the LV EF significantly decreased by $8.77 \%(P<0.05)$.

Distribution of types of LV geometric model in women with $C A D$, depending on the degree of BMD loss is presented in Fig. 1.

It has been established that the most prognostically unfavorable type of cardiac remodeling, which is the LV eccentric hypertrophy, was observed in $11.36 \%$ patients in the CAD and osteoporosis group, the proportion of concentric hypertrophy was $68.18 \%$, concentric remodeling occurred in $13.63 \% ; 6.82 \%$ of patients had a normal LV geometry. In the group of patients with coronary artery disease and osteopenia, eccentric hypertrophy was estimated in $8.82 \%$ of patients, concentric hypertrophy - in $64.71 \%$, concentric remodeling - in $11.76 \%$, normal geometry - in $14.71 \%$ of patients. In the group of patients with coronary heart disease without BMD disorders eccentric hypertrophy was found only in $4.17 \%$ of patients, LV concentric hypertrophy - in $70.83 \%$ of patients, while concentric remodeling was registered in $12.50 \%$, and the normal LV geometry was in $12.50 \%$ of cases.

Therefore, in patients with CAD, combined with postmenopausal osteoporosis, the significantly larger number of patients had an eccentric hypertrophy of LV if compared to the patients with normal BMD $\left(X^{2}=4.27\right.$; $\mathrm{df}=1 ; \mathrm{P}<0.05$ ).

Indices of transmitral blood flow in women in the postmenopausal period with $C A D$, depending on the degree of BMD loss are presented in Table 3.

Regarding the indices of transmitral blood flow in 
women with $\mathrm{CAD}$ and $\mathrm{BMD}$ disorders, the $\mathrm{Ve} / \mathrm{Va}$ ratio tended to decrease and isovolumic relaxation time of LV lengthening was observed if compared to the patients with CAD and normal BMD, which indicated an impairment of the lusitropic function of the heart. The DT in patients with bone structure changes was significantly longer than the same index in the group of patients with CAD without BMD loss: by $17.83 \%$ - in the group with CAD and osteopenia, by $21.03 \%$ - in the group with CAD and osteoporosis $(P<0.05)$.

In women with CAD, an increase in the incidence of LV diastolic dysfunction was observed, depending on the degree of BMD loss (Fig. 2).

As it was shown in Fig. 2, the diastolic dysfunction of the left ventricle, was observed more frequently with the progression of BMD loss: in $80.76 \%$ of women with CAD and osteoporosis $\left(X^{2}=5.96 ; d f=1 ; P<0.05\right)$; in $74.07 \%$ of $C A D$ and osteopenia patients $\left(X^{2}=3.87\right.$; $\mathrm{df}=1 ; \mathrm{P}<0.05)$ versus $42.86 \%$ of patients with normal bone turnover rate. No significant difference was observed between the groups considering the type of diastolic dysfunction: in all groups of patients the prevalence of diastolic dysfunction of impaired relaxation type was observed (in $100.00 \%$ - in the group of CAD patients, in $96.30 \%$ - in the group of patients with coronary artery disease with osteopenia, in $96.15 \%$ in the group of patients with coronary artery disease with osteoporosis).

In order to investigate the pecularities of cardiovascular remodeling in patients with coronary artery disease, the presence or absence of calcinosis of the valves of the heart and large vessels was determined, which suggests an increase in the incidence of ectopic calcification in patients with coronary artery disease with BMD disorders (Fig. 3).

As it was shown in Fig. 3, in the groups with BMD disorders, the number of patients with calcinosis of the valves of the heart and large vessels was significantly higher: $60.00 \%$ in the group with osteopenia $\left(X^{2}=3.77\right.$; $\mathrm{df}=1 ; \mathrm{P}<0.05) ; 77.42 \%$ in the group with osteoporosis $\left(X^{2}=9.79 ; \mathrm{df}=1 ; P<0.05\right)$ versus $28.58 \%$ in the group with normal BMD. Under the progression of BMD, an increase in the number of patients with coronary artery disease, with two or more valves calcinosis was observed, which was maximal in the group with osteoporosis: $45.16 \%\left(X^{2}=6.10 ; d f=1 ; P<0.05\right)$ versus $21.43 \%$ in group with normal BMD.

Under the conduction of the correlation analysis in the group of women with coronary heart disease and osteoporosis, a direct correlative interdependence between the T-and Z-criterion of the radial bone and the LV EF $(r=+0.42$; $P<0.05)$, between the 10-year risk of fracture of the phalanx and the RAD $(r=+0.50$; $P<0.05)$, between the Z-criterion of the radial bone and the LV ESD $(r=+0.61$; $P<0.05)$, between the 10 year risk of fracture of the radial and tibia bone and the LA-AP $(r=+0.43 ; P<0.05 ; r=+0.50 ; P<0.05$ correspondingly), the LVM $(r=+0.58$; $P<0.05)$ was discovered. In the group of women with coronary artery disease and osteopenia, a direct correlative dependence between the Z-criterion of the radial bone and the LV ESV $(r=+0.61$; $P<0.05)$, the LV EDV $(r=+0.63, P<0.05)$, between the Z-criterion

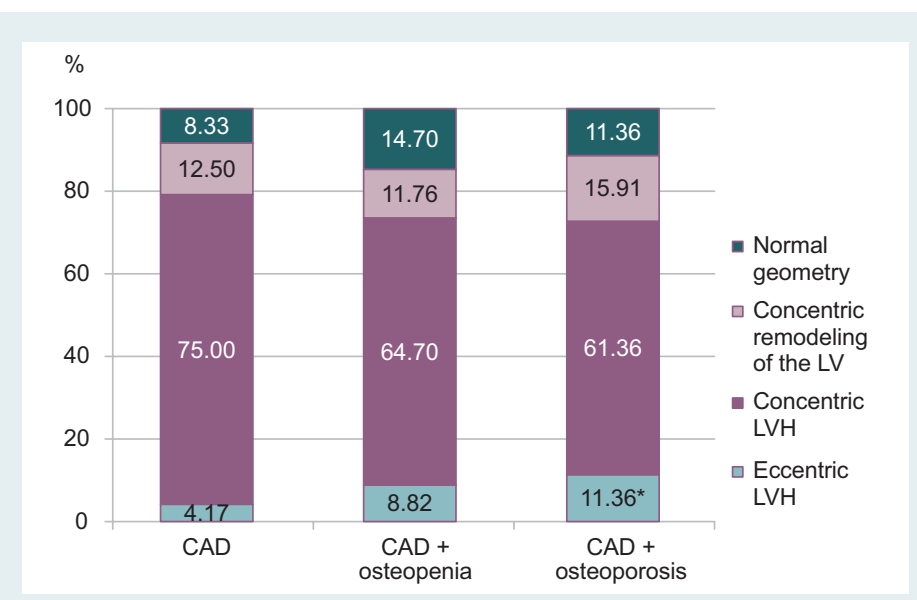

Fig. 1. Distribution of types of LV geometric model in women with CAD, depending on the degree of BMD loss.

*: the probability of indexes difference if compared to the patients with $C A D$ and normal BMD state according to the $X^{2}$ criterion $(P<0.05)$.

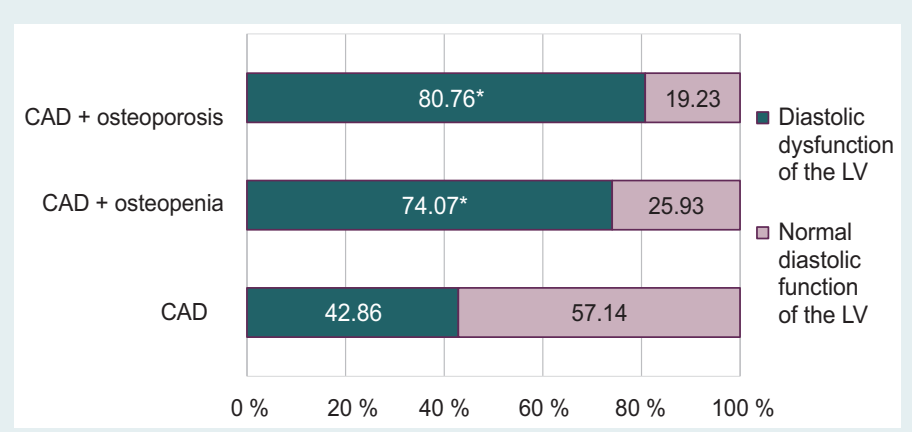

Fig. 2. Frequency of LV diastolic dysfunction in women with coronary artery disease, depending on the degree of BMD loss according to the echocardiography data.

*: the probability of indexes difference if compared to the patients with $C A D$ and normal BMD state, according to the $\mathrm{X}^{2}$ criterion $(\mathrm{P}<0.05)$.

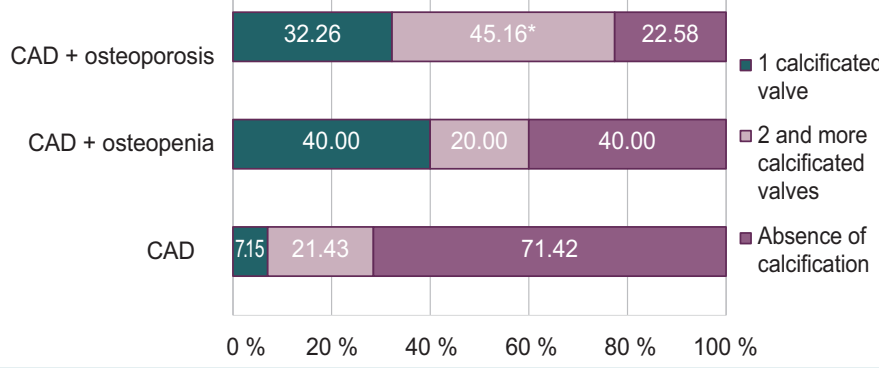

Fig. 3. Frequency of registration of calcinosis of the valves of the heart and large vessels in women with coronary artery disease, depending on the degree of BMD loss according to the echocardiography data.

*: the probability of indexes difference if compared to the patients with $C A D$ and normal BMD state according to the $x^{2}$ criterion $(P<0.05)$.

of the tibia and the diameter of the aorta $(r=+0.46$; $P<0.05)$, the inverse correlative dependence between the LVM and T-criterion of the tibia $(r=-0.75 ; P<0.05)$, the Z-criterion of the radial bone $(r=-0.64 ; P<0.05)$, the Z-criterion of the tibia $(r=-0.73 ; P<0.05)$ was found out.

Thus, the obtained data confirm the relationship between the BMD state and the indicators of cardiovascular remodeling in women with CAD. 


\section{Discussion}

In our study, in the group with CAD and postmenopausal osteoporosis, an increase in the IMC thickness was observed, a tendency to an increase in the LV EDV, the IVSd thickness and the LVMI, and a significantly higher thickness of the LV PWd and the LV ESV if compared to the patients with normal BMD was discovered, which indicates a greater degree of left ventricular hypertrophy, which leads to a significant increase in the LV Myocardial stiffness index. It should be noted that in women with CAD in the postmenopausal period in the structure of LV myocardial remodeling concentric hypertrophy was dominating, however, in the presence of concomitant postmenopausal osteoporosis, the frequency of development of eccentric hypertrophy of the myocardium as a predictor of disadaptive remodeling increases. The obtained data confirm the results of the research by Tsarenok S. Yu. (2017), who noted that the presence of osteoporosis in postmenopausal CAD patients is associated with an increase in the parameters of structural and geometric remodeling of the heart with predominance of the remodeling by the type of concentric LV hypertrophy [14].

In women with $\mathrm{CAD}$, in parallel with the decrease in BMD state, grade 1 diastolic dysfunction of the left ventricle was more common, which was verified by the $\mathrm{Ve} / \mathrm{Va}$ ratio tendency to decrease and LV isovulumic relaxation time slowdown lengthening, the significant DT increase if compared to the patients with CAD and normal BMD state. The data obtained coincide with the results of Wang R. et al. (2016) [15]. Thus, in the Wang's study, BMD loss was identified as an independent predictor of LV diastolic dysfunction, which can be explained by the effect of chronic inflammation with the hyperproduction of cytokines, growth factors, prostanoids, nitric oxide, and the development of oxidative stress in the combination with the endothelial dysfunction [15].

In the groups with BMD disorders, the number of patients who had calcinosis of two or more valves was significantly higher, and it was maximal in the group with osteoporosis. The studies of other authors also showed a link between calcification of the valves of the heart, coronary and peripheral arteries, and a decrease in BMD $[13,16-18]$, which can be explained by excessive activation of specific proteins (osteoprotegerin, osteocalcin), which leads not only to bone mineralization abnormalities, but also to the formation of ectopic calcification.

Thus, the obtained results confirm the existing scientific data on the presence of general pathogenetic mechanisms between the interruption of osteogenesis, the progression of cardiovascular remodeling and the development of heart valve calcinosis in women with $C A D$ in the postmenopausal period.

\section{Conclusions}

1. The development of postmenopausal osteoporosis in women with CAD is associated with a likely increase in the IMC of the left and right CCA (by $14.94 \%$ and $15.56 \%$ respectively), in the LV PWd (by $9.26 \%$ ), and in the LV Myocardial stiffness index (by $40 \%$ ), with a decrease in the LV EF (by $8.77 \%$ ). In women with CAD and osteopenia there was a similar directivity of cardioghemody- namic disorders, which have not reached the statistical significance level.

2. In women with CAD and postmenopausal osteoporosis, in the structure of LV myocardial remodeling concentric hypertrophy (68.18\%) and grade I diastolic dysfunction $(80.76 \%)$ were dominating, however, the increase of incidence of eccentric LV hypertrophy was observed if compared to the patients with normal BMD (11.36 \% vs. $4.17 \%$; $P<0.05)$.

3. In women with CAD and BMD disorders, a significantly higher number of patients with calcinosis of heart valves was observed: $60.00 \%$ in the group with osteopenia, $77.42 \%$ with osteoporosis compared with $28.58 \%$ in the group with normal BMD; an increase in the incidence of calcinosis in two or more heart valves was also discovered.

4. The peculiarities of changes in the structural and functional parameters of the heart in women with $C A D$ depend on the degree of BMD disorders, which indicates the presence of a interrrelationship between bone and cardiovascular remodeling and is confirmed by the corresponding data of the correlation analysis.

Prospects for further research: to assess the dynamics of cardiovascular remodeling indicators in women with CAD and postmenopausal osteoporosis under the influence of complex treatment is the prospect of further research.

\section{Funding}

The research was carried out within the scientific research work plan of the Zaporizhzhia State Medical University

on the topic: "Clinical and pathogenetic, prognostic and treatment and diagnostic aspects of cardiovascular pathology with different comorbid states" (State registration number 0118U007138).

Conflicts of interest: authors have no conflict of interest to declare. Конфмікт інтересів: віАсутній.

Надійшла до редакції / Received: 25.01.2019

Після Аоопрацювання / Revised: 14.03.2019

Прийнято Ао Аруку / Accepted: 25.03.2019

Information about authors:

Mykhailovska N. S., MD, PhD, DSc, Professor, Head

of the Department of General Practice - Family Medicine and Internal Diseases, Zaporizhzhia State Medical University, Ukraine. ORCID ID: 0000-0001-6781-9406

Stetsiuk I. O., MD, PhD Student of the Department of General Practice - Family Medicine and Internal Diseases, Zaporizhzhia State Medical University, Ukraine. ORCID ID: 0000-0002-3698-0181

Відомості про авторів:

Михайловська Н. С., А-р меА. наук, професор,

зав. каф. загальної практики - сімейної медицини та внутрішніх хвороб, Запорізький Аержавний меАичний університет, Україна. Стецюк І. О., аспірант каф. загальної практики - сімейної медицини та внутрішніх хвороб, Запорізький Аержавний медичний університет, Україна.

\section{Сведения об авторах:}

Михайловская Н. С., А-р меА. наук, профессор, зав. каф. общей практики - семейной медицины и внутренних болезней, Запорожский государственный меАицинский университет, Украина. 
Стецюк И. О., аспирант каф. общей практики - семейной медицины и внутренних болезней, Запорожский государственный медицинский университет, Украина.

\section{References}

[1] de Villiers, T., \& Tatarchuk, T. F. (2016) Natsionalnyi konsensus shchodo vedennia patsiientoku klimakterii [National consensus on the management of patients in menopause]. Reproductyvna endokrynolohia, 1(27), 8-25. [in Ukrainian]. doi: http://dx.doi.org/10.18370/2309-4117.2016.27.8-25

[2] Davis, S. R., Lambrinoudaki, I., Lumsden, M., Mishra, G. D., Pal, L., Rees, M., et al. (2015) Menopause. Nature Reviews Disease Primers, 1, 15004. doi: $10.1038 / n r d p .2015 .4$

[3] Mitchenko, O. I., \& Illiushyna, H. Ya. (2016) Rannia menopauza yak spetsyfichnyi faktor sertsevo-sudynnoho ryzyku v zhinok [Early menopause as a specific risk factor for cardiovascular risk in women]. Ukrainskyi kardiolohichnyi zhurnal, 3, 85-90. [in Ukrainian].

[4] Mitchenko, O. I., Mamedov, M. N., Kolesnik, T. V., Deev, A. D., Romanov, V. Yu., \& Ilyushina, G. Y. (2015) Osoblyvosti poshyrenosti chynnykiv sertsevo-sudynnoho ryzyku $v$ zhinok zalezhno vid naiavnosti menopauzy [Features of cardiovascular risk factors in women depending on menopause]. Ukrainskyi kardiolohichnyi zhurnal, 4, 96-102. [in Ukrainian].

[5] Pasieshvili, L. M. (2015) Osteoporoz - bezmolvnyj kostnyj vor [Osteoporosis is silent bone "Thief"]. Skhidnoievropeiskyi zhurnal vnutrishnoi ta simeinoi medytsyny, 1, 16-24. [in Russian].

[6] Golovach, I. Yu. (2018) Sovremennaya strategiya diagnostiki i dolgovremennogo lecheniya postmenopausal'nogo osteoporoza [Modern strategy of diagnostics and long-term treatment of postmenopausal osteoporosis]. Ukrainskyi revmatolohichnyi zhurnal, 2(72), 9-16. [in Russian].

[7] Barna, O., Golovach, I., Pogrebnyak, O., Korost, Ya., Pekhenko, V., Alifer, O., \& Lotushko, V. (2017) Otsinka stanu kistkovoi tkanyny za pokaznukamy UZ densytometrii u vikovomu aspekti (doslidzhennia SKELET) [Evaluation of the bone tissue state in terms of ultrasound densitometry in the age aspect (SCELET research)]. Liky Ukrainy, 8(214), 65-70. [in Ukrainian].

[8] Bugrim, T. V. (2014) Suchasni pidkhody do diahnostyky osteoporozu ta ishemichnoi khvoroby serdtsia $v$ zhinok u pisliamenopauzalnomy periodi v umovakh pervynnoi medyko-sanitarnoi dopomohy [Modern approaches to diagnostics of osteoporosis and ischemia in women after menopause under conditions of primary medical and sanitary aid]. Medychni perspektyvy, 19(1), 77-81. [in Ukrainian].

[9] Nishkumay, O. I. (2016) Kaltsyfikatsiia sudyn, ateroskleroz i osteoporoz: chy ye vzaiemozviazok? [Calcification of blood vessels, atherosclerosis and osteoporosis: is there a relationship?]. Sertse i sudyny, 1, 107-112. [in Ukrainian].

[10] Ahmadi, N., Mao, S. S., Hajsadeghi, F., Arnold, B., Kiramijyan, S. Gao, Y., et al. (2018) The relation of low levels of bone mineral density with coronary artery calcium and mortality. Osteoporos. Int., 29(7), 1609-1616. doi: 10.1007/s00198-018-4524-7

[11] Malyuta, E. B., Raskina, T. A., Barbarash, O. L., Kokov, A. N., Masenko, V. L., \& Voronkina, V. A. (2014) Vzaimosvyaz' osteopenicheskogo sindroma i porazheniya koronarnykh arterij u muzchin s ishemitcheskoj bolezn'yu serdca [Relationship between the osteopenic syndrome and coronary artery disease in male patients with ischemic heart disease]. Sovremennaya revmatologiya, 8(1), 18-22. [in Russian].

[12] Zhang, H., Wang, L. J., Si, D. L., Wang, C., Yang, J. C., Jiang, P., et al. (2015) Correlation between osteocalcin-positive endothelial progenitor cells and spotty calcification in patients with coronary artery disease. Clin. Exp. Pharmacol. Physiol., 42(7), 734-9. doi: 10.1111/14401681.12366

[13] Mykhailovska, N. S., \& Stetsiuk, I. O. (2018) The indicators of the bone tissue mineralization abnormalities in women with coronary artery disease in the post-menopausal period. Pathologia, 15, 2(43), 136-141. doi: 10.14739/2310-1237.2018.2.141408

[14] Tsarenok, S. Yu. (2017) Strukturno-funkcional nye izmeneniya miokarda $u$ zhenshchin s osteoporozom $v$ sochetanii $s$ ishemicheskoj bolezn' yu serdca [Structural and functional changes of myocardium in women with osteoporosis in combination with ischemic heart disease]. Klinicist, 11(3-4), 50-58. doi: 10.17650/1818-8338-2017-11-3-4-50-58 [in Russian].

[15] Wang, R. T., Li, X. S., Zhang, J. R., Sun, Y., Yu, K. J.,\& Liu, T. (2016) Bone mineral density is associated with left ventricular diastolic function in women, Clinical Cardiology, 39(12), 709-714. doi: 10.1002/clc.22592

[16] Sagalovsky, S., \& Richter, T. (2016). Kal'cifikaciya sosudov i osteoporoz: ot ponimaniya edinstva kletochno-molekulyarnykh mekhanizmov k poisku molekul kak potencial'nykh mishenej terapii [Vascular calcification and osteoporosis: from understanding common cellular and molecular mechanisms to search molecules as potential therapeutic targets]. Ukrainskyi kardiolohichnyi zhurnal, 1, 81-92. [in Russian].
[17] Tanna, N., Patel, K., Moore, A. E., Dulnoan, D., Edwards, S., \& Hampson, G. (2017) The relationship between circulating adiponectin, leptin and vaspin with bone mineral density (BMD), arterial calcification and stiffness: a cross-sectional study in post-menopausal women. J. Endocrinol. Invest., 40(12), 1345-1353. doi: 10.1007/s40618-017-0711-1

[18] Xu, R., Cheng, X. -C., Zhang, Y., Lai, H. -M., \& Yang, H. -N. (2018)Association of Severity of Coronary Lesions with Bone Mineral Density in Postmenopausal Women. Arquivos Brasileiros de Cardiologia, 110(3), 211-216. doi: $10.5935 / a b c .20180035$ 